\title{
As relações entre animais e humanos: uma breve arqueologia e discursos
}

\author{
The relations between animals and humans: a brief archeology of discourses
}

\author{
Carlos PIOVEZANI \\ Universidade Federal de São Carlos (UFSCar) \\ http://orcid.org/0000-0002-3612-983X \\ Manoel Sebastião ALVES FILHO \\ Universidade Federal de São Carlos (UFSCar) \\ http://orcid.org/0000-0002-4798-7581
}

\begin{abstract}
RESUMO: O artigo apresenta uma concisa série de considerações sobre a noção de discurso em Michel Foucault e sobre sua proposta de uma descrição arqueológica dos discursos, focalizando, em particular, os postulados foucaultianos acerca da "crítica do documento", "do arquivo" e das "unidades discursivas". Tais considerações são elaboradas com o intuito de expor a fundamentação teórica e metodológica a partir da qual identificamos e descrevemos uma profunda descontinuidade de discursos sobre as relações entre animais e humanos, que pode ser assim resumida: existência da linguagem entre eles, em uma posição, e embrutecimento dos bichos e destituição de sua linguagem, na outra. Esses discursos materializam-se em um conjunto de textos mitológicos e ritualísticos de sociedades ditas primordiais.
\end{abstract}

PALAVRAS-CHAVE: Discurso. Michel Foucault. Animais. Mitos.

ABSTRACT: The article presents a summary series of considerations about the notion of discourse in Michel Foucault and about his proposal for an archaeological description of the discourses, focusing, in particular, on Foucault's postulates about the "criticism of the document", the "archive", and the "discursive units". Such considerations are elaborated in order to expose the theoretical and methodological basis from wich we identify and describe a deep discontinuity of discourses about the relationship between animals and humans, wich can be summarized as follows: existence of language between them, in a position, and the stuttering of animals and the removal of their language in the other. These speeches are materialized in a set of mythological and ritualistic texts of so-called primordial societies.

KEYWORDS: Discourse. Michel Foucault. Animals. Myths.

\section{Introdução}

Logo após ter definido o discurso como "um conjunto de enunciados que se apoia em um mesmo sistema de formação" (1997, p. 126), Michel Foucault acrescenta que "o enunciado é, ao mesmo tempo, não visível e não oculto" (1997, p. 126). O filósofo francês inicialmente explica a razão pela qual o enunciado não está escondido: 
Não oculto, por definição, já que caracteriza as modalidades de existência próprias de um conjunto de signos efetivamente produzidos. A análise enunciativa só pode se referir a coisas ditas, a frases que foram realmente pronunciadas ou escritas, a elementos significantes que foram traçados ou articulados - e, mais precisamente, a essa singularidade que as faz existirem, as oferece à observação, à leitura, a uma reativação eventual, a mil usos ou transformações possíveis, entre outras coisas, mas não como as outras coisas. Só pode se referir a performances verbais realizadas, já que as analisa ao nível de sua existência: descrição das coisas ditas, precisamente, porque foram ditas (FOUCAULT, 1997, p. 126).

Um pouco mais à frente, Foucault (1997) nos dirá que não é pelo fato de que o enunciado não seja oculto que ele se torne imediata e facilmente visível. Eis as próprias palavras do filósofo:

Ora, por mais que o enunciado não seja oculto, nem por isso é visível; ele não se oferece à percepção como portador manifesto de seus limites e caracteres. É necessária uma certa conversão do olhar para poder reconhecê-lo e considerá-lo em si mesmo. Talvez ele seja tão conhecido que se esconde sem cessar; talvez seja como essas transparências familiares que, apesar de nada esconderem em sua espessura, não são apresentadas com clareza total (FOUCAULT, 1997, p. 128).

Mesmo que os enunciados de filósofos, de retores e de sofistas da Antiguidade ${ }^{1}$ ou ainda os de um filósofo moderno como Rousseau ${ }^{2}$ não tenham ocultado a existência de mecanismos e procedimentos de controle do dizer nem a existência do potencial ontológico das coisas ditas de criar os seres, as ações e os fatos de que falam, nem por isso a "ordem do discurso" se mostrou facilmente visível ao pensamento ocidental. Houve, ao contrário, várias e dispersas "filosofias", tais como "a filosofia do sujeito fundante", "a filosofia da experiência originária" e "a filosofia da mediação universal", que concorreram para apagar a condição material do discurso. É uma vez mais o próprio Michel Foucault que nos aponta esse apagamento, ao dizer que "parece que o pensamento ocidental tomou cuidado para que o discurso ocupasse o menor lugar possível entre o pensamento e a palavra" (2000, p. 46).

Em larga medida, devemos a Louis Althusser e, na sua esteira, a Michel Pêcheux, a Jacques Lacan e ao próprio Michel Foucault a conversão do olhar a partir da qual vimos emergir e se consolidar a "ordem do discurso" como um objeto de reflexão e análise. Apesar de suas diferenças, bastante e devidamente marcadas pela historiografia de curta duração ${ }^{3}$, há entre esses grandes nomes do chamado Estruturalismo francês

\footnotetext{
${ }^{1}$ Para conhecer aspectos dessa reflexão "discursiva" dos antigos, ver: Auroux (1989) e Cassin (2005).

2 Para conhecer as relações entre linguagem, sociedade e política em Rousseau, ver: Prado Júnior (2016).

${ }^{3}$ Para conhecer as diferenças entre Pêcheux e Foucault, ver: Gregolin (2004), Orlandi (2005) e Maldidier (2011).
} 
uma espécie de convergência na elaboração de um pensamento que concebe a noção de discurso e suas fundamentais relações com as ideologias e o inconsciente, com a constituição dos sujeitos e a produção dos sentidos ou com a formação dos saberes e o funcionamento dos poderes numa sociedade ${ }^{4}$.

Nestas nossas reflexões e análises dedicadas a demonstrar as descontinuidades entre dois discursos mitológicos acerca das relações entre seres humanos e animais, focalizando em particular a presença ou a ausência da linguagem atribuída pelos primeiros aos segundos, nos filiamos os Estudos discursivos foucaultianos. Por essa razão, antes de efetivamente procedermos às análises de mitos e ritos de sociedades ditas primordiais de tempos e espaços distintos, apresentaremos alguns dos principais postulados de Foucault a propósito do discurso, provenientes, em especial, da “Arqueologia do Saber". É com base nessa filiação que mais bem apontaremos como processos históricos e sociais produziram a passagem de uma relação humana sensível, respeitosa e não disjuntiva entre o universo humano e o que passamos a entender como "natureza" e a vida animal para uma relação fundamentada em um especismo, a partir do qual nos outorgamos o direito humano exclusivo de explorar e degradar nosso mundo e de dominar e matar animais de outras espécies.

\section{O discurso em "A Arqueologia do Saber” e a análise arqueológica das coisas ditas}

Foucault concebe o discurso como "a diferença entre o que poderíamos dizer corretamente em uma época e o que é dito efetivamente" (2020, p. 14). Isso porque, na dispersão da produção do dizer, há também a regularidade de uma prática que controla o que pode ser dito. Essas práticas "são um conjunto de regras anônimas, históricas, que definiram [...] as condições de exercício da função enunciativa" (2000, p. 135-136). Ademais, ao postular a existência de uma ordem do discurso, Michel Foucault diz que “em toda sociedade a produção do discurso é ao mesmo tempo controlada, selecionada, organizada e redistribuída por certo número de procedimentos" (2000, p. 8), cuja função é "conjurar seus poderes e perigos, dominar seu acontecimento aleatório, esquivar sua pesada e temível materialidade" (2000, p. 9).

Assim, Foucault sustenta que "não se tem o direito de dizer tudo, que não se pode falar de tudo em qualquer circunstância" (2000, p. 8), e, portanto, "que qualquer

\footnotetext{
${ }^{4}$ Para uma historiografia de média duração histórica, que correlaciona o Estruturalismo francês de meados do século XX e um antipsicologismo europeu do final do século XIX, ver: Puech (2016).
} 
um, enfim, não pode falar de qualquer coisa” (2000, p. 9). O discurso é marcado pela raridade, pois é o conjunto "sempre finito e efetivamente limitado das únicas sequências linguísticas que tenham sido formuladas" (FOUCAULT, 1997, p. 31). Ante essa condição rara do discurso, cabe a busca guiada pela seguinte questão: "como apareceu um determinado enunciado, e não outro em seu lugar?” (FOUCAULT, 1997, p. 31). A tentativa de lhe responder não pode descurar o fato de que na discursividade o que faz "a diferença e caracteriza a batalha dos discursos é a posição que é ocupada por cada um dos adversários" (FOUCAULT, 2001, p. 123-124).

Foucault (2001) nos ensina que diante de dizeres frequentemente muito semelhantes entre si é preciso identificar as posições enunciativas das quais eles provêm. Há, por exemplo, nos textos em que se materializam mitos e ritos que tratam das relações entre seres humanos e animais, enunciados, em princípio e ao mesmo tempo, bastante dispersos e muito similares entre si. A identificação das posições a partir das quais esses enunciados foram produzidos permite demonstrar que eles não somente constroem efeitos distintos, mas também e mais fundamentalmente engendram descontinuidades, que produzem discursos diversos e, por extensão, objetos e sujeitos, saberes e poderes diferentes e mesmo opostos. Disso deriva a afirmação de Paul Veyne a respeito das articulações entre as noções de discurso e de história em Foucault. Segundo Veyne (2011), Foucault revoluciona a história, entre outras razões, porque, diferentemente do trabalho historiográfico que concebe as transformações históricas como variações de um mesmo tema, as reflexões e análises arqueológicas e genealógicas do filósofo francês indicam profunda e minuciosamente as diferenças e singularidades de cada fenômeno histórico.

Esses e outros aspectos fundamentais da noção de discurso em Foucault concorrem para sua elaboração de uma descrição arqueológica das coisas ditas. Diante da impossibilidade de esgotar toda a riqueza e a produtividade que essa descrição compreende, optamos aqui por apresentar sumariamente somente três de seus princípios fundamentais: a crítica do documento, o tempo dos discursos e as unidades discursivas. No que se refere à crítica do documento, Foucault (1997) a identifica como uma contribuição dos avanços da historiografia de seu tempo. Ainda nas primeiras páginas do seu "Arqueologia do saber", ele relata a emergência da história que se dedica a longos períodos, a "grandes bases imóveis e mudas que o emaranhado das narrativas tradicionais recobria com toda uma densa camada de acontecimentos" (1997, p. 4), e a da história das ideias, das ciências, da literatura e da filosofia, cuja "atenção se 
deslocou, ao contrário, das vastas unidades descritas como 'épocas' ou 'séculos', para fenômenos de ruptura" (1997, p. 4, grifos do autor). A primeira, a história propriamente dita, a história pura simplesmente, "parece apagar, em benefício de estruturas fixas, a irrupção dos acontecimentos" (1997, p. 6), enquanto a outra "parece multiplicar as rupturas e buscar as perturbações da continuidade" (1997, p. 6).

É a partir da exposição desse entrecruzamento nos movimentos da historiografia que Foucault dirá que, apesar das aparências que indicam que algumas das disciplinas históricas "caminharam do contínuo para o descontínuo, enquanto que outras iam do formigamento das descontinuidades às grandes unidades ininterruptas" (1997, p. 7)", as duas tendências de estudos da história enfrentam os problemas que as conduzem ao que ele chama de a crítica do documento:

Pode-se resumir esses problemas em uma palavra: a crítica do documento. [...] Ora, por uma mutação que não data de hoje, mas que, sem dúvida, ainda não se concluiu, a história mudou sua posição acerca do documento; ela considera como sua tarefa primordial, não interpretá-lo, não determinar se diz a verdade nem qual é o seu valor expressivo, mas sim trabalhá-lo no interior e elaborá-lo (FOUCAULT, 1997, p. 7, grifo do autor).

Evidentemente, Foucault tinha razão ao afirmar que essa mutação não havia se concluído. Mais do que isso: ela se encontrava em constituição. Para sua consolidação, a publicação e a difusão de "A Arqueologia do Saber" foi fundamental. Isso porque ela nos legou uma distinção essencial, a saber, a que distingue o documento do monumento. É nestes termos que Foucault fala dessa distinção:

Digamos, para resumir, que a história, em sua forma tradicional, se dispunha a "memorizar" os monumentos do passado, transformá-los em documentos e fazer falarem estes rastros que, por si mesmos, raramente são verbais, ou que dizem em silêncio coisa diversa do que dizem; em nossos dias, a história é o que transforma os documentos em monumentos e que desdobra, onde se decifravam rastros deixados pelos homens, onde se tentava reconhecer em profundidade o que tinham sido, uma massa de elementos que devem ser isolados, agrupados, tornados pertinentes, inter-relacionados, organizados em conjuntos (FOUCAULT, 1997, p. 8, grifos do autor).

Bem mais adiante, ainda na "Arqueologia", Foucault volta a estabelecer essa diferença noutros termos. À descrição arqueológica, que "busca definir os próprios discursos, enquanto práticas que obedecem a regras" (FOUCAULT, 1997, p. 159), não cabe tratar:

o discurso como documento, como signo de uma outra coisa, como elemento que deveria ser transparente, mas cuja opacidade importuna é preciso atravessar frequentemente para reencontrar, enfim, aí onde se mantém a parte, a profundidade do essencial (FOUCAULT, 1997, p. 159, grifo do autor). 
Sua função é, antes, a de se dirigir "ao discurso em seu volume próprio, na qualidade de monumento" (FOUCAULT, 1997, p. 159, grifo do autor). Isso equivale a “interrogar a linguagem, não na direção a que ela remete, mas na dimensão que a produz" (FOUCAULT, 1997, p. 129) e ainda a "negligenciar o poder que ela tem de designar, de nomear, de mostrar, de fazer aparecer, de ser o lugar do sentido ou da verdade" (FOUCAULT, 1997, p. 129), para mais bem "se deter no momento que determina sua existência singular e limitada" (FOUCAULT, 1997, p. 129).

Em consonância com sua condição de monumento, outro aspecto relevante a ser observado no discurso refere-se ao tempo das coisas ditas, às suas maiores ou menores conservações e durações. Ao encontro do descompasso entre a generosa potência da lógica e da língua e os atos rarefeitos do discurso, existe a separação, em tudo o que foi dito, entre os textos e enunciados que serão mais ou menos conservados e aqueles que serão mais rapidamente esquecidos. A reflexão sobre o controle do dizer e de sua maior ou menor conservação está sintetizada na definição que Foucault (2010) consagra à noção de arquivo, que consiste num conjunto de regras que, em uma época dada e por uma sociedade determinada, definem os limites e as formas da dizibilidade, da conservação, da memória, da reativação e da apropriação.

Depois de assim tê-lo definido nesse seu texto que prefigura a "Arqueologia", neste último Foucault volta a lhe dar uma conceituação análoga, esclarecendo a particular relação entre o tempo e o discurso, na qual se vê que o tempo do discurso, isto é, sua efemeridade ou sua perenidade não dependem da cronologia:

O arquivo é, de início, a lei do que pode ser dito, o sistema que rege o surgimento dos enunciados como acontecimentos singulares. Mas o arquivo é também o que faz com que todas as coisas ditas não se acumulem indefinidamente em uma massa amorfa, não se inscrevam, tampouco, em uma linearidade sem ruptura e não desapareçam ao simples acaso de acidentes externos, mas que se agrupem em figuras distintas, se componham umas com as outras segundo relações múltiplas, se mantenham ou se esfumem segundo regularidades específicas; ele é o que faz com que não recuem no mesmo ritmo que o tempo, mas que as que brilham muito forte como estrelas próximas venham até nós, na verdade de muito longe, quando outras contemporâneas já estão extremamente pálidas (FOUCAULT, 1997, p. 149).

A função desempenhada pelo arquivo não é a de unificar "tudo que foi dito no grande murmúrio confuso de um discurso" (FOUCAULT, 1997, p. 149, grifo do autor), não é tampouco a de nos assegurar "a existência no meio do discurso" (FOUCAULT, 1997, p. 149, grifo do autor), mas é, de fato, a de diferenciar "os discursos em sua existência múltipla” e de especificá-los em sua duração própria” (FOUCAULT, 1997, p. 
149, grifo do autor). Sua reflexão sobre os tempos do discurso não se resume à centralidade do arquivo na descrição arqueológica dos enunciados. Porque ela é bastante cara ao pensamento de Foucault acerca da discursividade, assistiremos a um seu retorno nas considerações que ele faz sobre a noção de "comentário" em "A ordem do discurso". Em meio a sua exposição dos procedimentos internos de controle do discurso, Foucault discorre sobre o comentário e então formula a hipótese de que:

\begin{abstract}
há, muito regularmente nas sociedades, uma espécie de desnivelamento entre os discursos: os discursos que 'se dizem' no correr dos dias e das trocas, e que passam com o ato mesmo que os pronunciou; e os discursos que estão na origem de certo número de atos novos de fala que os retomam, os transformam ou falam deles, ou seja, os discursos que, indefinidamente, para além de sua formulação são ditos, permanecem ditos e estão ainda por dizer (FOUCAULT, 2000, p. 22, grifo do autor).
\end{abstract}

Uma vez que a descrição arqueológica postulada por Foucault consiste em analisar discursos, é preciso enfrentar o problema de se deparar com objetos empíricos e a partir deles se chegar ao objeto teórico. Com efeito, numerosos e dispersos textos e enunciados em seu estado bruto não são satisfatoriamente triados e inscritos em unidades, séries ou conjuntos que os reúnam com base no fato de que tratariam de um suposto objeto comum. Tampouco são pertinentes e produtivos os grupos formados a partir do que foi dito acerca desse "mesmo" objeto em campos de saber previamente constituídos nos quais se lhe dispensou atenção ou ainda do que foi formulado pela diversidade dos indivíduos que o tematizou em seus enunciados. Ora, é o exame da ordem do discurso que nos permite apreender devidamente as regularidades e as unidades discursivas. Em sua "Arqueologia”, Foucault sustenta que para fazê-lo é necessário pôr em suspenso temas, noções e princípios que conveniente e frequentemente são acionados quando se tem de identificar e descrever a emergência histórica de discursos.

Os temas, noções e princípios que devem ser suspensos são a "tradição" e a "influência", o "desenvolvimento" e a "evolução", a "mentalidade" e o "espírito da época", o "livro" e a "obra" e ainda a impossibilidade de "assinalar, na ordem do discurso, a irrupção de um acontecimento verdadeiro" (FOUCAULT, 1997, p 28) e o princípio "segundo o qual todo discurso manifesto repousaria secretamente sobre um jádito" (FOUCAULT, 1997, p. 28). Todos eles cumprem o papel de reagrupar a dispersão de acontecimentos discursivos diversos, no interior dos quais emergem distintos referenciais, diferentes modalidades enunciativas, distintos domínios associados e diferentes materialidades. Ao proceder desse modo a esse reagrupamento, apagam-se as 
diferenças enunciativas e as singularidades dos acontecimentos. Foucault diz que é preciso "renunciar a esses temas que têm por função garantir a infinita continuidade do discurso e sua secreta presença no jogo de uma ausência reconduzida" (1997, p. 28).

Essa renúncia é, antes, uma suspensão, dado que, se, por um lado, é necessário suspender "todas essas sínteses que não problematizamos e que deixamos valer de pleno direito" (FOUCAULT, 1997, p. 29), por outro, não devemos necessariamente excluí-las de modo definitivo, porque:

\begin{abstract}
Não se trata, é claro, de recusá-las definitivamente, mas sacudir a quietude com a qual as aceitamos; mostrar que elas não se justificam por si mesmas, que são sempre o efeito de uma construção cujas regras devem ser conhecidas e cujas justificativas devem ser controladas; definir em que condições e em vista de que análises, algumas são legítimas; indicar as que, de qualquer forma, não podem mais ser admitidas.[...] Enfim, que exigem uma teoria; e que essa teoria não pode ser elaborada sem que apareça o campo dos fatos do discurso a partir do qual são construídas (FOUCAULT, 1997, p. 29).
\end{abstract}

A necessidade não de empreender uma exclusão definitiva, mas de efetuar uma suspensão e/ou uma modificação no modo de se conceber e de interrogar essas sínteses, é formulada ainda por Foucault (1997) em outra modalidade enunciativa, que faz com que, desta feita, a relação entre o enunciador e o enunciado seja mais próxima e bem mais intrincada, tal como algo entre uma espécie de admissão de culpa e um anúncio de uma operação inevitável. Se a operação é inevitável, nem por isso ela não é passível de reconfigurações. Assim, Foucault diz que inicialmente levará em consideração unidades inteiramente formadas, mas que não se colocará no interior dessas unidades. Antes, irá questionar sua formação e verificar se não se constituem como um "efeito de superfície de unidades mais consistentes" (1997, p. 30).

Considerando todas essas reflexões do filósofo sobre o discurso e sua descrição arqueológica que aqui resumimos, particularmente essas acerca da "crítica do documento" e das noções de "arquivo" e de "unidades discursivas", é que nos propomos a alcançar este objetivo: elaborar o esboço de uma breve arqueologia de discursos sobre as relações entre os animais e os seres humanos, nos valendo da crítica do documento, de modo a tomar as coisas ditas como monumentos e não como documentos, buscando identificar e descrever os distintos tempos desses discursos, de maneira a conferir e mais bem compreender suas diversas durações, suas retomadas, suas reformulações, seus apagamentos e suas conservações, e delimitando as diferentes unidades discursivas, de 
forma a apontar suas emergências históricas e as descontinuidades que se estabelecem entre elas 5 .

\section{Uma breve arqueologia de discursos sobre as relações entre animais e humanos ${ }^{6}$}

Nesta seção, procederemos às análises de discursos mitológicos e ritualísticos sobre as relações entre homens e animais que sociedades ditas primordiais de tempos e espaços distintos nos legaram através de narrativas orais ou de textos escritos, assim como de reflexões a seu respeito produzidas por pesquisadores contemporâneos. Partimos de unidades discursivas comuns, como certos campos do saber humano, cronônimos, autores e obras, com vistas a suspendê-las e a identificar em enunciados delas extraídas discursos mais fundamentais, cujas forças e alcance fazem com que ultrapassem esses domínios de saber, passem de um a outro autor, se expandam, transponham as fronteiras do tempo e do espaço, das eras e dos lugares e configurem descontinuidades discursivas ao longo da história. Mais especificamente, trata-se de indicar, em nossa história, a passagem de dizeres que concebem os animais como criaturas divinas, conscientes e linguageiras, a quem o homem deve reverência e com as quais estabelece um contrato de morte caracterizado por certos procedimentos ritualísticos, para dizeres que concebem os animais como criaturas mortais, brutas e mudas, a quem o ser humano não deve respeito algum e aos quais mata sem quaisquer cerimônias.

Joseph Campbell tem uma vasta e reconhecida produção científica dedicada a produções simbólicas que tratam de relações instauradas entre seres humanos e animais durante o longo período ao qual a ciência moderna chama de Pré-história. O autor destaca que as cavernas paleolíticas conservaram dois tipos de evidência desse contato: pinturas rupestres teriomórficas e crânios de ursos adornados com ossos, pedras e dispostos sobre um tipo de altar (CAMPBELL, 1992). Interessa-nos aqui refletir acerca de certo discurso que se materializa nos textos de Campbell e que se filia a um movimento científico que, não sem dissensos, acredita que os primeiros povos eram caçadores-coletores, viviam em planícies e utilizavam as cavernas como ambientes

\footnotetext{
${ }^{5}$ Dois exercícios nessa direção foram empreendidos em Courtine e Piovezani (2015) e em Piovezani (2020).

${ }^{6}$ Estas análises foram realizadas originalmente por Alves Filho (2020) e adaptadas aqui com vistas à publicação deste artigo. Seu mestrado foi financiado pela Coordenação de Aperfeiçoamento de Pessoal de Nível Superior - CAPES.
} 
sagrados que cumpriam, entre outros papéis, o de abrigar cerimonias relacionadas com a prática de caçar os animais.

Para Campbell, os povos do paleolítico viviam em um ambiente hostil, com recursos naturais escassos e rodeados de fenômenos ameaçadores, além de disporem de um domínio bastante limitado sobre a própria natureza. Bisões, ursos e outros animais se mostravam muito poderosos em relação aos homens pré-históricos, eram raros e caçá-los compreendia muitos riscos para os caçadores. Para tentar garantir o seu ressurgimento periódico e o sucesso da caçada, os caçadores realizavam, então, cerimônias consagradas aos próprios animais que matavam. Supõe-se que na cosmogonia desses homens certos bichos eram considerados deuses dotados de qualidades como consciência e linguagem, com quem os caçadores estabeleceram um pacto: os animais ofereciam voluntariamente seus próprios corpos como alimento desde que os seres humanos lhes rendessem cultos, garantindo o retorno de suas almas à natureza. Assim, o urso que havia sido morto e que teve o crânio cuidadosamente retirado do corpo como parte de um ritual ressurgia na estação seguinte para repetir o ciclo da vida e da morte. As caçadas, por sua vez, eram precedidas de sua representação nas pinturas rupestres das cavernas: os animais eram desenhados com flechas nos flancos para que pudessem ser atingidos efetivamente nos prados.

Essa reconstrução detalhada de práticas de caça do homem no paleolítico não se apoia unicamente nos resquícios arqueológicos que dissemos, mas em mitos e ritos de sociedades ditas primordiais. Campbell pesquisou cosmogonias de diferentes povos ao redor do mundo e se surpreendeu com as similaridades que encontrou. Para explicar essas equivalências, o autor nos apresenta à teoria difusionista de que os mitos e ritos se espalharam pelo planeta a partir do continente europeu, com as migrações humanas, se reconfigurando e se ajustando às necessidades e aos processos singulares das novas sociedades. Para reconstruir a vida no paleolítico, ele, como outros cientistas de sua época, realizou uma análise comparativa entre os resquícios arqueológicos encontrados nas cavernas com as mitologias de sociedades contemporâneas ditas primordiais e entendeu que os nossos antepassados hominídeos nutriam pensamento semelhante aos segundos a respeito do universo animal.

Seguindo a abordagem do mitólogo estadunidense, de que essas cosmovisões derivaram do mesmo tronco genealógico e se espalharam através de povos, períodos e lugares diversos, acreditamos que a análise discursiva de mitos e ritos de sociedades ditas primordiais podem esclarecer algumas das características e transformações nas 
relações entre seres humanos e animais durante o período pré-histórico e o início da Antiguidade greco-latina. Estes aspectos e modificações, que enfrentaram refluxos e recrudescimentos, conservações e mais fundamentalmente descontinuidades ao longo do tempo, são essenciais para que possamos mais bem compreender as relações que estabelecemos com os animais em nossa época, na medida em que iluminam diferenças entre práticas e discursos atuais. Assim, podemos realizar um importante diagnóstico do presente, tal como nos ensinou Foucault.

Os primeiros mitos e ritos que analisaremos provêm da sociedade tribal Pésnegros. Ela é nativa do estado norte-americano de Montana e seus membros foram grandes caçadores de búfalos, como se supõe que foram os caçadores pré-históricos. Uma das estratégias que os nativos punham em prática para eliminar uma grande quantidade desses animais consistia em atraí-los para um rochedo e abatê-los depois que saltassem. Na véspera da caçada, o pajé desembrulhava o cachimbo e pedia ao sol que obtivessem sucesso. Na manhã seguinte, ele e os caçadores acordavam cedo e se dirigiam aos prados. Enquanto os demais se escondiam atrás das rochas, o xamã, mascarado com um crânio de búfalo e coberto com um manto feito da pele do animal, se aproximava da manada para chamar sua atenção.

Alguns demonstravam interesse por aquela presença inusitada e eram conduzidos na direção desejada, fazendo com que, em seguida, o grupo todo se movimentasse aos poucos rumo às proximidades do precipício. Quando a manada estava muito próxima do penhasco, os cúmplices humanos saíam dos rochedos e começavam a gritar e a sacudir os seus próprios mantos, semelhantes ao do primeiro. $\mathrm{O}$ movimento inesperado assustava o último búfalo do grupo, que empurrava os companheiros e provocava sua queda. A base da montanha havia sido previamente cercada, de modo que os que não morriam com a colisão eram eliminados em seguida. Esse povo tem um mito a respeito da sua relação com esses animais e de como essas práticas do xamã e dos caçadores começaram. Os Pés-negros narraram oralmente ao antropólogo George Bird Grinnell essa história, cuja síntese se encontra em Campbell (1992), de onde a extraímos.

O mito que originou o rito descrito brevemente acima começa com uma situação atípica para os Pés-negros. Os caçadores da tribo não conseguiam induzir os animais à queda e pereciam de fome. Uma jovem nativa, então, gritou para os búfalos que estavam pastando no penhasco acima dela que, se eles pulassem, como de costume, ela se casaria com um deles. Para a surpresa da menina, os animais começaram a pular, e 
um dos sobreviventes, um grande touro, lhe disse que ela agora teria que se casar com ele e a raptou. Depois que a tribo finalmente se alimentou dos búfalos que haviam morrido com a colisão, o pai da garota sentiu a sua falta e partiu em uma jornada para procurá-la. Depois de percorrer os prados, o genitor encontra a menina em um lamaçal com os búfalos. O grande touro, entretanto, sente o seu cheiro, o descobre e o mata. Enquanto a menina pranteia a morte do pai, o animal se apieda da situação e lhe diz:

\begin{abstract}
'Ah-ah', Exclamou o touro. 'Você está chorando por seu pai. Assim, talvez, agora você possa entender como é conosco. Temos visto nossas mães, pais e muitos de nossos familiares rolando rochas abaixo e sendo massacrados pelo seu povo. Mas terei compaixão de você; dar-lhe-ei apenas uma chance. Se você conseguir trazer seu pai de volta à vida, você e ele poderão retornar para juntos dos seus'. Ela o descobriu, seu pai respirava, e então ergueu-se. Os búfalos ficaram surpresos. [...]

'Agora', disse, 'antes que você e seu pai vão embora, nós vamos ensinar-lhes nossa dança e nosso canto. Vocês não devem esquecê-los'. Pois esses eram os meios mágicos pelos quais os búfalos, mortos pelas pessoas para se tornarem alimento delas, seriam restituídos à vida, exatamente como o homem morto pelos búfalos. [...] 'Agora, vão para sua casa e não se esqueçam do que viram. Ensinem essa dança e esse canto a seu povo. Os objetos sagrados desse rito devem ser a cabeça de um touro e a pele de um búfalo. (CAMPBELL, 2020, p. 233).
\end{abstract}

Podemos identificar duas posições discursivas no interior do mito dos aborígenes de Montana. A primeira, representada pela menina e os membros de sua sociedade, manifesta os interesses humanos, que devem caçar e matar outros animais ao seu redor para que possam se alimentar. Mas é importante observar, entretanto, que o mito também materializa os interesses e o ponto de vista dos animais, com a inclusão do mestre búfalo, porta-voz dos membros de sua própria espécie. Eles não são considerados objetos, mas criaturas dotadas de linguagem, uma vez que conversam com os homens, de consciência, pois compreendem o mundo ao seu redor, de sensibilidade e relações de parentesco, porque lamentam o massacre dos membros de suas famílias, de cultura, já que sabem cantar e dançar, de religião e alma, pois creem no plano espiritual. Essas duas posições e suas duas perspectivas se encontram no diálogo estabelecido entre a garota e o mestre animal e nos acontecimentos que se desenrolam na história dessa sociedade. $\mathrm{O}$ dissenso entre as duas perspectivas é enfim resolvido com o pacto firmado entre ambos. Joseph Campbell não deixou de notar que a tribo Aranda da Austrália Central tem um mito semelhante relativo a essa relação contratual entre homens e animais, materializado, desta vez, com a presença dos cangurus, seres próprios daquele ambiente, e que uma pintura rupestre dentro de Les Trois-Frères 
retrata uma cena em que um caçador trajando cabeça e manto de búfalo parece dançar em torno de alguns animais.

Já em um dos relatos de expedição do etnólogo e arqueólogo alemão Leo Frobenius (apud CAMPBELL, 1992) pelo Continente Africano, nós também encontramos elementos importantes sobre práticas de caça. Nos primeiros anos do século passado, na República Democrática do Congo, quatro pigmeus, três homens e uma mulher, compunham uma expedição em que se encontrava o cientista. Em um entardecer, este, já bastante entrosado com o grupo de nativos e ciente de que eles eram excelentes caçadores, lhes pediu que caçassem um antílope. O pedido, natural para um europeu cuja cultura hegemônica concebe o corpo animal como um objeto, um produto de consumo, chocou, porém, os pigmeus, que tinham outra concepção. Eles responderam que ficariam felizes em lhe prestar o favor, mas que nenhum preparativo havia sido feito para a caçada, de maneira que naquele dia seria impossível realizá-la. A diversidade de pensamento em relação ao tema interessou o alemão. Seu interesse fez com que ele se despertasse antes da aurora, no dia seguinte, para ver o que os aborígenes africanos realizariam. Eis um trecho do seu relato:

\begin{abstract}
Os homens agacharam-se no chão e limparam toda a área de vegetação, e depois a alisaram. Um deles então riscou algo na terra com o dedo, enquanto os outros homens e a mulher murmuravam fórmulas rituais e orações; em seguida, fez-se silêncio enquanto eles esperavam por algo. $\mathrm{O}$ sol surgiu no horizonte. Um dos homens, com uma flecha no seu arco estirado, encaminhou-se para o terreno limpo. Em alguns instantes os raios do sol atingiram o risco no chão e, no mesmo instante, ocorreu o seguinte na velocidade do raio: a mulher ergueu as mãos como se fosse alcançar o sol e pronunciou em voz alta algumas sílabas ininteligíveis; então o homem disparou sua flecha, a mulher gritou novamente, os homens correram para a floresta com suas armas. [...] Saí de meu esconderijo e vi que o que tinha sido desenhado no chão era um antílope de cerca de $1,20 \mathrm{~m}$ de comprimento: e a flecha estava enterrada no seu pescoço. [...] Os caçadores nos alcançaram naquela tarde com um belo corço. Ele tinha sido abatido com uma flecha no pescoço. Os homenzinhos entregaram sua caça e foram, então, com alguns tufos de seus pelos e uma cabaça cheia de sangue para seu lugar na montanha. (FROBENIUS apud CAMPBELL, 1992, p. 250-251).
\end{abstract}

Esse relato nos mostra duas concepções diferentes a respeito dos animais ocorrendo simultaneamente. De um lado, podemos observar o entendimento de um típico homem ocidental do século passado, para quem um animal selvagem não passava de um alimento em potencial, enquanto do outro, observamos uma compreensão distinta, envolvendo uma relação contratual entre caçador e caça, atualizada mediante os procedimentos ritualísticos realizados pelos pigmeus, incluindo representar a criatura, que seria posteriormente acossada, na areia, e atingi-la com uma arma. O historiador da arte Ernst Gombrich (2013) escreveu, em um estudo sobre a arte rupestre das cavernas 
paleolíticas, que imagem e realidade estavam interligadas para os seres humanos préhistóricos: parte dessas figuras retratam cenas de caça, com animais marcados com flechas etc. O ritual dos pigmeus nos mostra que essa prática ancestral ainda persistia até um século atrás. O caçador deve golpear a reprodução do animal para atingi-lo fisicamente na caçada. Ele precisa também cumprir o pacto que estabeleceu com a criatura para que esta possa reaparecer na natureza e ser caçada novamente ${ }^{7}$.

Esse desencontro entre concepções é constantemente explorado pelo diretor de animações Hayao Miyazaki. Fundador do Studio Ghibli, ele explora em alguns de seus filmes o contraste entre crenças milenares a respeito do cuidado com a natureza e com os animais, e a destruição provocada por práticas levadas a cabo pela sociedade contemporânea. Em Princesa Mononoke (1997), encontramos elementos de uma cosmogonia das sociedades ditas primordiais. O filme começa com Ashitaka, o príncipe de uma vila campestre, enfrentando um grande javali, outrora um protetor da floresta, mas que havia se tornado um demônio. O menino o detém, mas o bicho lhe toca na pele e lhe passa uma chaga, uma maldição. Quando, já ferido gravemente, o javali dá seus últimos suspiros, a anciã da tribo, como manda os mitos e ritos primordiais, se ajoelha perante o bicho e lhe diz que fará um monumento em sua homenagem. O javali, porém, tomado pela cólera, não aceita a oferta e os amaldiçoa. Quando o animal falece, descobrimos que ele foi atingido por uma bala de metal. A morte, portanto, não foi natural: o contrato que havia sido firmado entre o homem e o animal fora transgredido, provocando aquela reação colérica e inesperada.

O príncipe, amaldiçoado pelo contato com o javali, consulta a anciã da tribo e esta lhe diz que a ferida se espalhará e o matará. No intuito de descobrir uma cura que o livre daquela maldição, ele é instruído a procurar a origem da bala que causou tamanho ódio e sofrimento ao animal. Em sua jornada, o protagonista encontra uma vila que fabrica armas de fogo e que está em processo de industrialização. Liderados por Lady Eboshi, os habitantes da cidade desmatam a floresta e enfrentam constantemente os lobos, estes últimos comandados por San, uma jovem que crescera com eles. No decorrer da história, a regente da cidadela se alia a um homem para matar o Grande Espírito da Floresta, enquanto o jovem Ashitaka e a amiga dos lobos San se unem para tentar frustrar os seus planos.

\footnotetext{
7 O povo Aino, originário das ilhas japonesas Hokkaido, Sakhalin e Kurilas, tem uma cosmogonia semelhante que se materializa em sua relação com os ursos negros.
} 
Embora o filme faça uma crítica ao mundo atual, anunciando a industrialização e suas nefastas consequências naturais, essas mudanças de discursividade sobre os animais podem ser encontradas em outros discursos provenientes do campo ao qual a ciência convencionou chamar de mitologia. A análise de outros mitos sugere que, à medida que o ser humano foi se desenvolvendo e alicerçando seu domínio sobre o mundo natural, o animal foi perdendo seu status divino e suas antigas características, notadamente a linguagem. Em consequência, o homem perdeu a tradição de cultuá-los e suas mortes se tornaram uma prática banal. Podemos perceber essa lenta mutação em cosmogonias cujas deidades sofreram hibridismo: elas já não são mais totalmente animalescas. É o caso de deuses egípcios, hindus e mesmo os metamorfos deuses gregos. Enfim, nas religiões abraâmicas, os animais perdem o protagonismo divino de forma drástica, sujeitos aos seres humanos e a um deus cuja antropomorfização havia se tornado completa e definitiva.

O Popol Vuh, códice dos Maias-Quiché de Quauhtlemallan, registra algumas passagens interessantes em relação ao estatuto dos animais, à ausência de linguagem e à banalização de suas vidas. No princípio do mundo, as deidades conceberam primeiramente os bichos. Então ordenaram o seguinte: “Agora falem, invoquem. Não gorjeiem, não gritem. Falem nossos nomes, louvem-nos" (2019, p. 124). Apesar da tentativa, as criaturas não corresponderam às expectativas. "Eles não falavam como gente” (2019, p. 124), não eram pessoas, não eram como os humanos seriam, pois só “soltavam chilreios, cacarejos, rugidos" (2019, p. 124), e não palavras articuladas. Como não falavam seus nomes, como não os adoravam, os deuses viram que aquilo não era bom e disseram-lhes: "Vocês serão mudados, pois não deu certo, não conseguiram falar" (2019, p. 124-125). E então: "E vocês, só acatem seu serviço, só deixem sua carne ser comida. É isso. Essa será sua serventia" (2019, p. 124-125).

Os animais são enviados aos grotões e às florestas, e a sua função reduz-se a servir de alimento. Desprovidos de fala, "suas carnes foram abatidas, e esta virou sua serventia: que fossem comidos, que fossem mortos os bichos aqui no leito da terra" (POPUL VUH, 2019, p. 125). Seu status é diminuído e o homem assume o protagonismo da criação, impera sobre a natureza e os demais seres vivos. Antes, assim como agora, o homem comia os animais, mas já não há preocupação em respeitá-los, em garantir que suas almas regressem ao plano material. Progressivamente, os discursos dos povos ancestrais sobre os animais sofrem variações e constituem uma profunda 
descontinuidade. Dessa constituição resulta que estes últimos deixam de ser vistos como seres cujas vidas importam à espécie humana.

O povo Juruna do Parque Indígena do Xingu também tem uma cosmogonia na qual os animais perderam a fala. Sua divindade, Sela' $\tilde{a}$, descendente de um pai onça e de uma mãe humana, receando a solidão, criou outros seres humanos e bichos-gente, animais que também possuíam traços antropomórficos. Entretanto, apesar destes compartilharem alguns atributos físicos com aqueles, não tinham seus modos, sobretudo porque falavam erradamente a linguagem humana. Sendo assim, a deidade anunciou: "Essas pessoas não são nossos parentes. Não são verdadeiros. Depois vão virar bicho" (FARGETTI, 2017, p. 42). Os animais passaram por um processo de embrutecimento: já não falam, já não impõem condições às suas mortes, já não são capazes de articular seus interesses.

Finalmente, o sobrevoo que fizemos por mitos e ritos de sociedades ancestrais de lugares e tempos distintos se encerra com uma passagem de um texto clássico da Antiguidade. Nas Metamorfoses de Ovídio (2017), os homens são constantemente transfigurados em animais para que se calem, característica que nos mostra que os animais passam a ser concebidos pela elite letrada e ilustrada da Grécia antiga como seres sem linguagem. Dentre todas essas histórias, a mais significativa dessa descontinuidade de práticas e discursos talvez seja a do jovem Acteão. Ele caçava com seus cães em um vale quando se deparou com a deusa Daiana se banhando em um lago. A deidade, ultrajada por ter sido avistada nua, o transforma em cervo para que não conte o episódio. Despojado de linguagem, o transmorfo é morto pelos seus próprios cães caçadores: “ao ver na água a sua figura e os chifres, ia para dizer 'Triste de mim!' Não teve palavras. Bramiu. Foi essa a sua voz" (OVÍDIO, 2017, p. 178) ${ }^{8}$.

\section{Considerações Finais}

Realizamos um breve percurso pelas ideias de Foucault a respeito da ordem do discurso e de seu funcionamento, nos concentrando em "A Arqueologia do Saber", que,

\footnotetext{
${ }^{8}$ Para saber mais sobre as diferenças entre a linguagem humana e a voz animal entre gregos e latinos na Antiguidade, ver: Piovezani e Salazar (2016). Para saber mais sobre as relações entre animais e humanos, ver: Alves Filho (2020), além de Alves Filho e Piovezani (2020a, 2020b). Para saber mais sobre rituais e cosmologias de sociedades indígenas brasileiras, ver: Neves e Cardoso (2015).
} 
depois de cinquenta anos de publicação, continua a ser uma fonte incontornável para a reflexão sobre a discursividade e as análises de discursos. De sua descrição arqueológica das coisas ditas, optamos por apresentar de modo sumário três postulados fundamentais: a crítica do documento, o tempo dos discursos e as unidades discursivas. Finalmente, articulamos esses conceitos em uma análise de discursos mitológicos acerca das relações entre seres humanos e animais, focalizando em particular a presença ou a ausência de linguagem atribuída pelos primeiros aos segundos e suas consequências. $\mathrm{Na}$ esteira de Foucault, nosso ponto de partida foram unidades discursivas comuns, como certos campos do saber humano, cronônimos, autores e obras, cuja suspensão foi necessária para que pudéssemos identificar discursos mais fundamentais, que as ultrapassam e que configuram descontinuidades discursivas ao longo da história. Tratamos os documentos históricos como monumentos, isolando, agrupando, relacionando e organizando certos conjuntos de elementos. Não seguimos uma cronologia linear, mas diferenciamos os discursos em sua existência múltipla e os analisamos em sua própria duração. Nossas análises evidenciaram uma descontinuidade profunda entre dois discursos. O primeiro concebia os animais como seres divinos, dotados de consciência e de linguagem articulada, a quem os homens deviam respeito e reverência, estes últimos materializados em certos procedimentos ritualísticos. O segundo, por sua vez, concebia os animais como seres mortais, brutos e mudos, com quem o homem já não mais estabelecia uma relação respeitosa e contratual. Um diagnóstico de nosso presente, em que se instala uma sociedade ao mesmo tempo sensível à causa animal e predadora e mortífera em escala industrial jamais vista, não pode descurar de refletir sobre essa descontinuidade que, embora tão antiga, se metamorfoseia e se faz presente em nossos dias.

\section{Agradecimentos}

Agradecemos ao Conselho Nacional de Desenvolvimento Científico e Tecnológico CNPq [Processo no 308559/2017-7], à Coordenação de Aperfeiçoamento de Pessoal de Nível Superior - CAPES e à Fundação de Amparo à Pesquisa do Estado de São Paulo FAPESP [Processo n ${ }^{\circ}$ 2019/17099-6] pelo financiamento de nossas pesquisas.

\section{REFERÊNCIAS}


ALVES FILHO, M. S. Homem, animal, indústria: uma análise discursiva do agronegócio brasileiro (Dissertação de Mestrado). Universidade Federal de São Carlos, São Paulo, 2020.

ALVES FILHO, M. S.; PIOVEZANI, C. O que mostram e o que apagam os discursos publicitários da indústria da carne brasileira. Acta Scientiarum. Language and Culture, v. 42, n. 1, p. e52015, 12 de maio 2020a.

ALVES FILHO, M. S.; PIOVEZANI, C. Sentidos do agronegócio brasileiro: o discurso publicitário da Friboi. Revista do GEL, v. 17, n. 2, p.11-35, 2020 b.

AUROUX, S. (Dir.) Histoire des idées linguistiques. Liége/Bruxelas: Pierre Mardaga, 1989.

CAMPBELL, J. As Máscaras de Deus, v. 1: mitologia primitiva. Tradução de Carmen Fischer. São Paulo: Palas Athena, 1992.

CASSIN, B. O efeito sofístico. Tradução de Ana Oliveira, Maria Ferraz e Paulo Pinheiro. São Paulo: Editora 34, 2005.

COURTINE, J-J.; PIOVEZANI, C. (Orgs.). História da fala pública: uma arqueologia dos poderes do discurso. Petrópolis: Vozes, 2015.

FARGETTI, Cristina Martins. Fala de bicho, fala de gente: cantigas de ninar do Povo Juruna. São Paulo: Ed. Sesc, 2017.

FOUCAULT, M. Arqueologia do saber. Tradução de Luiz Neves. Rio de Janeiro: Forense, 1997.

FOUCAULT, M. A ordem do discurso. Tradução de Laura Sampaio. São Paulo: Loyola, 2000.

FOUCAULT. M. Le discours ne doit pas être pris comme... In: Dits et écrits. vol. II. Paris: Gallimard, 2001, p. 123-124.

FOUCAULT. M. Resposta a uma questão. Tradução de Ana Pessoa. Ditos \& Escritos. vol. VI. Rio de Janeiro, RJ: Forense, 2010, p. 1-24.

GREGOLIN, M. R. V. Foucault e Pêcheux na Análise do Discurso: diálogos e duelos. São Carlos, SP: Claraluz, 2004.

GOMBRICH, E. A História da arte. Tradução de Álvaro Cabral. Rio de Janeiro: LTC, 2013.

MALDIDIER, D. A inquietude do discurso. In: PIOVEZANI, C.; SARGENTINI, V. (Orgs.) Legados de Michel Pêcheux: inéditos em Análise do discurso. São Paulo: Contexto, 2011, p. 39-62.

NEVES, I. S.; CARDOSO, A. S. P. Patrimônio Cultural Tembé-Tenetehara: terra indígena alto rio Guamá. Belém: Iphan-PA, 2015.

ORLANDI, E. Michel Foucault e Michel Pêcheux: relação pelo discurso. In: FALCÃO, L.; SOUZA, P. (org.) Michel Foucault: perspectivas. Rio de Janeiro: Achiamé, 2005, p. 65-70.

OVÍDIO. Metamorfoses. Tradução de Domingos Dias. São Paulo: Editora 34, 2017.

PIOVEZANI, C.; SALAZAR, P-J. A voz humana na era das redes sociais. Cadernos De Estudos Linguísticos, 2016, 58 (1), p. 167-178. 
PIOVEZANI, C. A voz do povo: uma longa história de discriminações. Petrópolis: Vozes, 2020.

PRADO JÚNIOR, B. A retórica de Rousseau. São Paulo: Cosac \& Naïfy, 2008.

PUECH, C. O 'discurso', as heranças e os destinos de Saussure na França. Tradução de Carlos Piovezani et. al. In: CRUZ, M. A.; PIOVEZANI, C.; TESTENOIRE, P-Y.

(Orgs.) Saussure, o texto e o discurso: 100 anos de heranças e recepções. São Paulo: Parábola, 2016, p. 13-38.

POPOL VUH: O esplendor da palavra antiga dos Maias-Quiché de

Quauhtlemallan: aurora sangrenta, história e mito. Tradução de Josely Baptista: São Paulo: Ubu, 2019.

PRINCESA MONONOKE. Direção: Hayao Miyazaki. Japão: Studio Ghibli, 1997. 1 DVD (134 min).

VEYNE, P. Foucault, seu pensamento, sua pessoa. Tradução de Luís Lima. São Paulo: Civilização Brasileira, 2011. 